\title{
Increased Expression Levels of Metalloprotease, Tissue Inhibitor of Metalloprotease, Metallothionein, and p63 in Ectopic Endometrium: An Animal Experimental Study
}

\section{Aumento nos níveis de expressão de metaloprotease, inibidor tecidual das metaloproteases, metalotioneina e p63 em endométrio ectópico: um estudo experimental animal}

\author{
Verônica Cristina Moraes Brandão ${ }^{1,2}$ Juliana Meola ${ }^{1}$ Sergio Britto Garcia ${ }^{1}$ \\ Francisco José Candido-dos-Reis ${ }^{1}$ Omero Benedicto Poli-Neto ${ }^{1}$ Antonio Alberto Nogueira ${ }^{1}$ \\ Julio Cesar Rosa-e-Silva ${ }^{1}$ \\ ${ }^{1}$ Faculty of Medicine, Universidade de São Paulo, Ribeirão Preto, SP, Brazil \\ 2 Faculty of Medicine, Universidade Federal do Mato Grosso, Cuiaba, \\ MT, Brazil \\ Address for correspondence Julio Cesar Rosa-e-Silva, MD, PhD, \\ Av. Bandeirantes, 3900, 14049-900, Vila Monte Alegre, \\ Ribeirão Preto, SP, Brazil (e-mail: juliocrs@usp.br).
}

Rev Bras Ginecol Obstet 2018;40:705-712.

\begin{abstract}
Objective To characterize the patterns of cell differentiation, proliferation, and tissue invasion in eutopic and ectopic endometrium of rabbits with induced endometriotic lesions via a well- known experimental model, 4 and 8 weeks after the endometrial implantation procedure.

Methods Twenty-nine female New Zealand rabbits underwent laparotomy for endometriosis induction through the resection of one uterine horn, isolation of the endometrium, and fixation of tissue segment to the pelvic peritoneum. Two groups of animals (one with 14 animals, and the other with15) were sacrificed 4 and 8 weeks after endometriosis induction. The lesion was excised along with the opposite uterine horn for endometrial gland and stroma determination. Immunohistochemical reactions were performed in eutopic and ectopic endometrial tissues for analysis of the following markers: metalloprotease (MMP-9) and tissue inhibitor of metalloprotease (TIMP-2), which are involved in the invasive capacity of the endometrial tissue; and metallothionein (MT) and p63, which are involved in cell differentiation and proliferation.

Results The intensity of the immunostaining for MMP9, TIMP-2, MT, and p63 was higher in ectopic endometria than in eutopic endometria. However, when the ectopic lesions were compared at 4 and 8 weeks, no significant difference was observed, with

Keywords

- endometriosis

- cell differentiation

- cell proliferation

- tissue invasion the exception of the marker p63, which was more evident after 8 weeks of evolution of the ectopic endometrial tissue.

Conclusion Ectopic endometrial lesions seem to express greater power for cell differentiation and tissue invasion, compared with eutopic endometria, demonstrating a potentially invasive, progressive, and heterogeneous presentation of endometriosis.
\end{abstract}

received

March 28, 2018

accepted

September 3, 2018
DOI https://doi.org/

10.1055/s-0038-1675612. ISSN 0100-7203.
Copyright (e 2018 by Thieme Revinter

Publicações Ltda, Rio de Janeiro, Brazil
License terms

(c) (1) 


\section{Resumo}

\section{Palavras-chave \\ - endometriose \\ - diferenciação celular \\ - proliferação celular \\ - invasão tecidual}

Objetivo Caracterizar o padrão de diferenciação celular, proliferação e invasão tecidual em endométrio eutópico e ectópico de coelhas com lesões de endometriose induzidas por um modelo experimental 4 e 8 semanas após o procedimento de implantação endometrial.

Métodos Vinte e nove coelhas fêmeas Nova Zelândia foram submetidas a laparotomia para indução de endometriose através da ressecção de um dos cornos uterinos, isolamento do endométrio e fixação do tecido no peritônio pélvico. Dois grupos de animais (14 animais em um grupo e 15 animais no outro) foram sacrificados 4 e 8 semanas após a indução da endometriose. A lesão foi excisada junto com o corno uterino contralateral para determinação da presença de glândulas e de estroma endometrial. Reações de imunohistoquímica foram realizadas no tecido endometrial eutópico e ectópico para análise dos seguintes marcadores: metaloprotease (MMP9) e inibidor tecidual da metaloprotease 2 (TIMP-2), os quais estão envolvidos na capacidade de invasão do tecido endometrial; e metalotioneina (MT) e p63, os quais estão envolvidos na diferenciação e proliferação celular.

Resultados A intensidade da imunomarcação para MMP9, TIMP-2, MT e p63 foi mais alta nos endométrios ectópicos do que nos endométrios eutópicos. Contudo, quando as lesões foram comparadas entre 4 e 8 semanas, nenhuma diferença foi observada, com exceção do marcador p63, o qual foi mais evidente depois de 8 semanas de evolução do tecido endometrial ectópico.

Conclusão Lesões endometriais ectópicas parecem expressar maior poder de diferenciação celular e de invasão tecidual comparadas com endométrios eutópicos, demonstrando o potencial de invasão, de progressão e de apresentação heterogênea da endometriose.

\section{Introduction}

The etiopathogenesis of endometriosis is controversial. ${ }^{1}$ Several theories have been proposed, such as the presence of retrograde menstrual flow associated with an immunological predisposition in the peritoneal microenvironment that facilitates the implantation of viable endometrial cells and has the potential for implantation. ${ }^{2}$ Recent studies suggest that the endometria of patients with endometriosis have an invasive and aggressive behavior, and higher expression levels of substances related to cellular invasion, cellular differentiation, and proliferation, such as metalloproteases (MMPs) and tissue inhibitors of MMPs (TIMPs), ${ }^{3-11} \mathrm{p} 63,{ }^{12-16}$ and metallothionein (MT) ${ }^{17-19}$ have been described.

Metalloproteases are a family of endopeptidases that play a role in degrading and remodeling the extracellular matrix. They are zinc dependent and include collagenase, gelatinase, and stromal enzymes. Their activities are regulated by TIMPs. ${ }^{20}$ The production of MMPs and of TIMPs occurs in the endometrial stroma and in the epithelium, as well as in polymorphonuclear leucocytes. Another important source of these enzymes are macrophages, neutrophils, and eosinophils, activated in response to a certain degree of inflammation present in the peritoneal cavity of women with endometriosis. ${ }^{21-23}$

The membrane protein p63 is a marker of cell differentiation, homologous to the tumor protein suppressor p53, and is expressed in basal squamous and subcolumnar reserve cells in the uterine cervix, in the breasts, in the salivary glands, and in the prostate. ${ }^{24}$ It regulates proliferation and epithelial differentiation. $^{25}$

Metallothionein is a low-molecular-weight protein that performs functions in cell growth, repair, and proliferation. ${ }^{26}$ The perinuclear location of MT is known to be important in the protection against DNA damage and apoptosis induced by external stressors. ${ }^{27,28}$

The use of female rabbits in experimental models of endometriosis is characterized by the development of homogeneous lesions, generally solid hemorrhagic masses, which are easily produced through an autotransplant of endometrial fragments or through the opening and exposure of the endometrial cavity. ${ }^{29,30}$ In addition, rabbits were chosen as the experimental animals because of their low infection rate, which makes antibiotic administration unnecessary. ${ }^{31}$

In the experimental model conducted in our service, ${ }^{32}$ the development of lesions after endometrial tissue implantation was $100 \%$ after 4 and 8 weeks, with the presence of stroma and gland on histological observation, a fact also reported in other experimental studies. ${ }^{31,33}$

The objective of the present study was to characterize the proliferation, differentiation, and invasion behavior in eutopic and ectopic endometria in rabbits submitted to the induction of endometriosis lesions by using a known experimental model, 4 and 8 weeks after the endometrial implantation procedure. 


\section{Methods}

\section{Animals}

The present study was performed in the experimental surgery sector of the department of surgery and anatomy of the Hospital das Clínicas, Ribeirão Preto, State of São Paulo and in the department of pathology of the Faculty of Medicine of Riberão Preto of the Universidade de São Paulo, state of São Paulo, Brazil. It was approved by the ethics committee for animal experimentation by the same institution. After the sample calculation, the size of the study group was set at 10 animals. However, considering the possibility of losses, 15 adult animals were included per group, with one loss (death) during the experiment, therefore totaling 29 adult New Zealand female virgin rabbits from the vivarium of the Faculty of Medicine of Ribeirão Preto. The rabbits were kept in appropriate cages under the same conditions for 3 days before the induction of the lesions. All of the rabbits were submitted to a laparotomy under general anesthesia with intravenous administration of $3 \mathrm{~mL}$ of thionembutal (2.5\%) along with $1 \mathrm{~mL}$ of xylestesin (2\%).

\section{Induction Technique for Endometriotic Lesions}

The pelvic cavity was opened with a median longitudinal incision of $\sim 2 \mathrm{~cm}$ in length, $2 \mathrm{~cm}$ from the pubis of the animal. Then, $\sim 4 \mathrm{~cm}$ of the right uterine horn was resected and then the horn was closed. The portion of the uterine that was resected was immersed in $0.9 \%$ saline solution for $\sim 2$ minutes for tissue cleaning and then cut longitudinally, resecting a $5 \times 5-\mathrm{mm}$ fragment. This endometrial tissue fragment was sutured to the peritoneum near the reproductive tract of the rabbits by using 2 simple Vicryl 6.0 (Ethicon Inc., Sommerville, NJ, USA) sutures, with the endometrium was facing inward facing the abdominal cavity, with posterior closing of the abdominal surgical incision. No hormonal supplements were administered before or after the laparotomy. The same observer performed all of the procedures. ${ }^{32}$

\section{Removal of Lesions for Histological Analysis}

The rabbits were divided into two groups, namely group 1 , which consisted of 14 animals whose lesion evolution time was 4 weeks, and group 2, which consisted of 14 animals with a lesion evolution time of 8 weeks. After pelvic inspection, identification, and documentation of the lesion, the rabbits were sacrificed. The lesion, along with the left uterine horn (contralateral), was excised for histological analysis. The excised tissues were set in $10 \%$ formaldehyde and processed for inclusion in paraffin. After preparing the slides, the tissues were stained with hematoxylin and eosin (H\&E) stain for histological analysis. The analysis results indicated that $100 \%$ of the samples in both groups were composed of active endometrial (gland and stroma) tissues, with similar morphological characteristics. The lesions were characterized by thin-walled cysts located on the striated muscle of the abdominal wall, projecting toward the abdominal cavity. The cyst walls were formed by a thin layer of connective tissue, rich in cells, and covered by simple squamous epithelium. The stroma is rich in fibroblasts, and contains some macrophages and eosinophils in addition to a large quantity of typical endometrial glands. The evaluation of the lesions in two stages has the purpose of verifying the presence of any tissue modification during the progression of the lesions, as well as their growth.

\section{Immunohistochemical Techniques}

Histological sections (4-5 mm) were submitted for histochemical analysis with the antigen-antibody reaction. The reaction was developed by using a marker visible under the microscope. The deparaffinized and hydrated sections were recovered antigenically by incubation in a buffered medium in a steam pot for 40 minutes. After cooling, the endogenous tissue peroxidases were removed by adding hydrogen peroxide, and horse serum was added to prevent nonspecific binding of the primary antibody. The slides were then incubated with primary antibodies obtained from Novocastra Laboratories Ltd. (Newcastle upon Tyne, United Kingdom). The samples were then evaluated regarding the following markers: MT (1:100; clone E9; Dako North America Inc., Carpinteria, CA, USA) and p63 (1:500; clone BC4A4; Biocare Medical, Concord, CA, USA), which are related to cell proliferation and differentiation, and MMP 9 (1:100 clone 15W2; Leica Biosystems, Wetzlar, Germany) and TIMP-2 (1:100 clone 3A4; Novocastra Laboratories, United Kingdom), which are involved with invasive capacity. The materials were then incubated with the secondary antibody and submitted to the avidin-biotin step. The reaction was developed by treatment with 3.30-diaminobenzidine (SigmaAldrich Inc., St. Louis, MO, USA) for 5 minutes. Thereafter, the materials were counterstained with Harris H\&E stain and mounted on slides. The immunohistochemical markers were analyzed quantitatively and manually, counting the number of marked cells in thousands, and divided into 4 quadrants of 250 cells each. All of the slides were evaluated by two pathologists experienced in immunohistochemistry who were blinded to the type of tissue to be analyzed.

\section{Statistical Analysis}

A statistical analysis was performed by using the GraphPad Prism 5.0 32-bit executable software (GraphPad Software Inc., San Diego, CA, USA). The paired Student $t$-test was used for variables with a normal distribution and for comparison of the paired data. The non-paired Student $t$-test was used for variables with normal distribution and non-paired data. Finally, the Mann-Whitney U-test was used for non-paired variables with non-normal distribution. The level of statistical significance was set at $5 \%$.

\section{Results}

A significantly more intense stain for MMP9, TIMP-2, MT, and p63 were observed in the ectopic endometria than in the eutopic endometria. (-Table 1 and -Fig. 1). However, regarding the ectopic lesions that were compared at 4 and 8 weeks, no significant differences were observed, with the exception of the p63 indicator, which was more evident after 8 weeks of ectopic endometrial tissue progression. ( - Table 2 and - Fig. 1). 
Table 1 Cellular immunostaining according to endometrial types

\begin{tabular}{|l|l|l|l|}
\hline & $\begin{array}{l}\text { Topic } \\
\text { mean } \pm \text { SD }\end{array}$ & $\begin{array}{l}\text { Ectopic } \\
\text { mean } \pm \text { SD }\end{array}$ & $p$-value \\
\hline MMP-9 & $0.273 \pm 0.147$ & $0.364 \pm 0.223$ & 0.0003 \\
\hline TIMP-2 & $0.249 \pm 0.126$ & $0.274 \pm 0.152$ & 0.02 \\
\hline Metallothionein & $0.277 \pm 0.141$ & $0.361 \pm 0.220$ & 0.0003 \\
\hline p63 & $0.218 \pm 0.080$ & $0.276 \pm 0.095$ & $<0.0001$ \\
\hline
\end{tabular}

Abbreviations: MMP-9, metalloprotease; SD, standard deviation; TIMP-2, tissue inhibitor of metalloprotease.
Table 2 Cellular immunostaining in ectopic endometrium according to progression time

\begin{tabular}{|l|l|l|l|}
\hline & $\begin{array}{l}4 \text { weeks } \\
\text { mean } \pm \text { SD }\end{array}$ & $\begin{array}{l}8 \text { weeks } \\
\text { mean } \pm \text { SD }\end{array}$ & $p$-value \\
\hline MMP-9 & $0.418 \pm 0.209$ & $0.314 \pm 0.231$ & 0.21 \\
\hline TIMP-2 & $0.288 \pm 0.152$ & $0.262 \pm 0.157$ & 0.66 \\
\hline Metallothionein & $0.428 \pm 0.221$ & $0.298 \pm 0.208$ & 0.11 \\
\hline p63 & $0.240 \pm 0.058$ & $0.309 \pm 0.113$ & 0.05 \\
\hline
\end{tabular}

Abbreviations: MMP-9, metalloprotease; SD, standard deviation; TIMP-2, tissue inhibitor of metalloprotease.

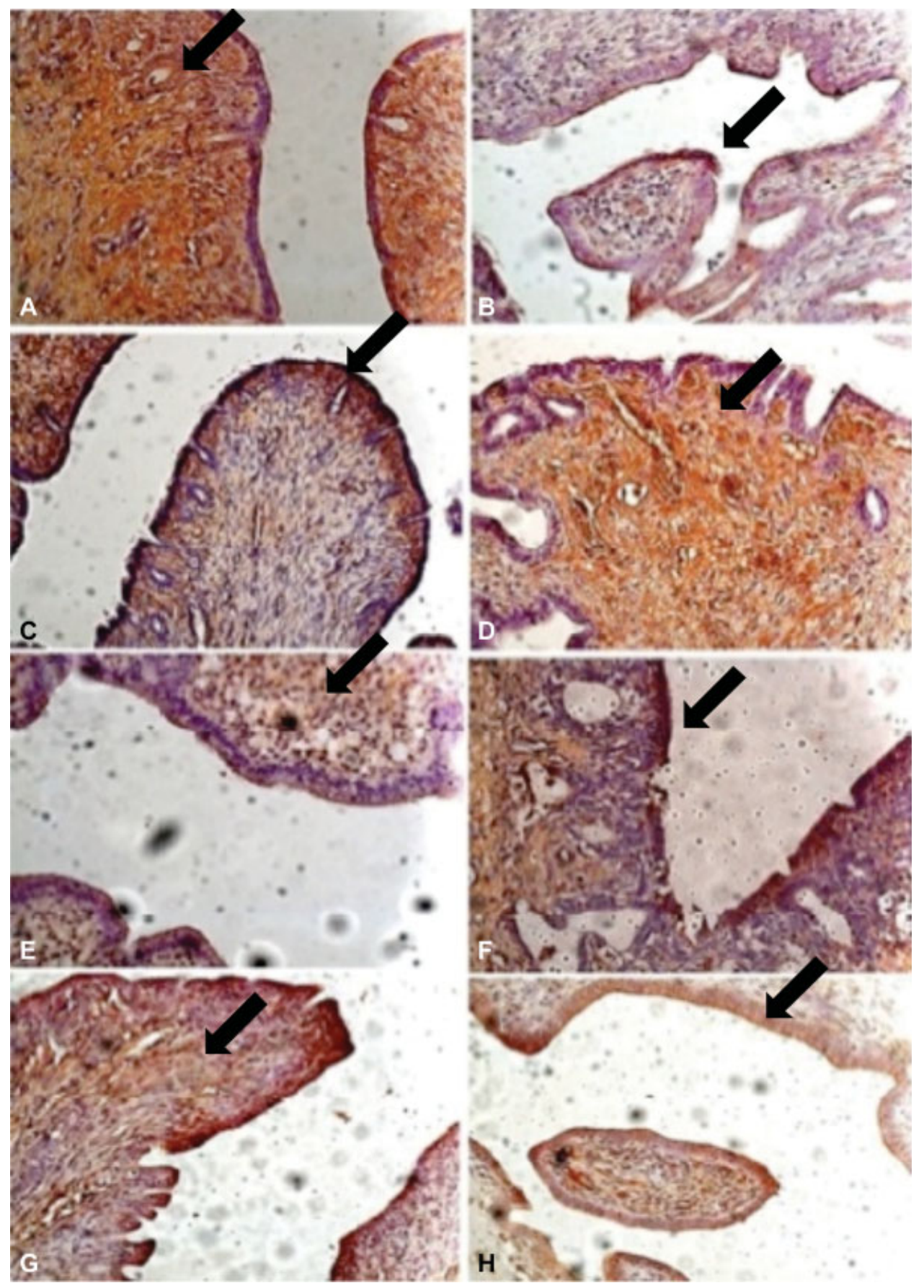

Fig. 1 Immunostaining by: metalloprotease in the eutopic (A) and ectopic endometria (B); tissue inhibitor of metalloprotease in the eutopic (C) and ectopic endometria (D); metallothionein in the eutopic $(\mathrm{E})$ and ectopic endometria $(\mathrm{F})$; and p63 in the eutopic $(\mathrm{G})$ and ectopic endometria $(\mathrm{H})$. 40x enlargement. 


\section{Discussion}

In the present study, we have demonstrated that the ectopic endometrial lesions showed a higher number of immune stained cells expressing cellular invasion markers (MMP-9 and its inhibitor TIMP-2) and of molecules involved in cellular proliferation and differentiation (MT and p63) than the eutopic endometrial lesions, using a rabbit experimental model of endometriosis. However, when 4- and 8week ectopic lesions were compared, there was no significant difference except for the p63 marker, which was more evident after 8 weeks of evolution of the ectopic endometrial tissue. This suggests that this marker increases the longer the period of lesion evolution, demonstrating a greater capacity of differentiation of the ectopic endometriotic foci. ${ }^{34}$

The MMP system is formed by an enzymatic component, MMP, and by an inhibiting component, the TIMPs. It has been well established that this system performs a critical role during the normal development and growth of the endometrium, as well as many other physiological processes. ${ }^{35}$

Metalloproteases have been implicated in the pathogenesis of endometriosis, the greater part of which are synthesized during the proliferative phase and stimulated by estrogen expression. Inversely, progesterone levels reduce MMP transcription and secretion. In an endometriosis model using mice and human endometria, endometrial treatment with estrogen led to an increase in MMP production and in endometrial ectopic implantation. In contrast, treatment with progesterone, which inhibits the production of MMP ${ }^{36}$ or TIMP-1, decreased the success rate of ectopic implantation. ${ }^{37-39}$

Metalloproteases work on the dynamics of the degradation and remodeling process of the extracellular matrix, stimulating cellular proliferation and apoptosis, as well as inducing cellular migration. Several previous studies suggest that eutopic and ectopic endometria in women with endometriosis present altered levels of the MMP/TIMP system, indicating that these two enzymes play a role in the pathogenesis of the illness. In general, the irregular synthesis and secretion of MMPs by endometriosis lesions, combined with aberrant quantities of TIMP-1 in the peritoneal fluid, could disturb the normal proteolytic environment of the peritoneal cavity, thus inducing a more aggressive behavior and facilitating invasion by ectopic cells. The exact mechanisms that lead to the aberrant expressions of MMPs and their tissue inhibitors in endometriosis have yet to be defined. ${ }^{3,36,40-47}$

Meanwhile, studies inferred that the increased expression levels of MMPs in the peritoneal fluid and in ectopic lesions in endometriosis patients could be a secondary event that results from an innate difference in peritoneal and systemic factors instead of from alterations in the endometrium, causing an abnormal peritoneal response to the menstrual reflux, which in turn facilitates ectopic implantation. ${ }^{48}$

Vinatier et al $(2000)^{49}$ suggested that the characteristics of endometrial cells differ between women with and without endometriosis. The endometrium in women with endometriosis has an increased capacity for proliferation and implantation in ectopic locations. Therefore, the interpretation of the results should consider that eutopic endometrial cells and refluxed cells in the peritoneal cavity are not regulated by the same environment. Refluxed cells in the peritoneal cavity are regulated by the microenvironment of the peritoneal fluid, contrary to eutopic endometrial cells, which are regulated by blood flow factors. This concept of a different environment is rarely considered when eutopic and ectopic endometria are compared. The differences that are observed should be interpreted not only as differences in tissue characteristics, but also as a result of environmental differences. The type of cellular modification along with local factors such as the microenvironment of the peritoneal fluid or the intraovarian environment will determine if they will develop typical lesions, deep endometriosis, or ovarian cysts. ${ }^{49,50}$

The present study observed a higher immunostaining intensity of MMP-9 and its inhibitor, TIMP-2, in ectopic endometria, which was related to a higher ability to proliferate and to the invasive capacity of these tissues, as shown in previous studies. ${ }^{3-11}$

Although the progression time of these lesions did not interfere in a statistically significant way in the MMP-9 ( $p=0.214)$ and in the TIMP-2 staining $(p=0.66)$, our results suggest that the evaluation of MMP-9 and TIMP-2 could be used as a prognostic indicator of endometrial invasion; therefore, increasing the proteolytic activity would be one of the many factors that contribute to the invasive properties of the endometrium, resulting in the development of endometriosis.

The molecular alterations observed in the human endometrium during the menstrual cycle could be crucial to the reproductive function. The accumulation of cytotoxic cells increases the exposure of endometrial cells to apoptosis, and protection against this process could be reached by selfregulating cellular mechanisms, suggesting that MT participates in this context. Significant differences in MT expression observed in the endometrium regarding alterations in the menstrual cycle could suggest the participation of MT in the protection against apoptosis in endometrial cells. ${ }^{51}$

Metalloprotease takes part in the detoxification process of organisms, being found in benign and malignant neoplasms, among others, in animals and humans, mainly in the $S$ phase of the cellular cycle. It is considered as an index for cell proliferation and tumor progression. During proliferation, epithelial cells have a higher expression level of MT, indicating an increase in the number of dividing cells, particularly during the $S$ phase of the cell cycle. This is why MT could be considered as a marker of endometriosis. ${ }^{18}$

The perinuclear location of MT is known to be important for protection against DNA damage and apoptosis induced by external stressors. ${ }^{27}$ Therefore, the MT expression in endometrial cells could favor their persistence in ectopic localization, as reported by Wicherek et al (2006). ${ }^{19}$

We have observed a higher-intensity stain in ectopic endometrial tissue in comparison with eutopic tissue; however, the difference was not statistically significant regarding the progression time of the lesion in the ectopic tissue.

Data suggest that MT expression seems to be under hormonal control in normal endometrium and that MT could modify the $\mathrm{p} 53$ expression and be used as a biological marker of aggressive behavior in endometrial lesions. ${ }^{17}$ The ability of 
the endometrium to distinguish cytotoxic activity from increased protection against DNA damage (MT expression), as well as concomitant changes in the number of cells in the immune system and its activity, which are observed in normal endometrium during the phases of the menstrual cycle, seems to be fundamental for the pathological characteristics of endometriosis. $^{52}$

The p63 protein has been described as a marker of basal and reserve cells in the female genital tract, ${ }^{53-55}$ being strongly related with altered differentiation, including metaplasia, either isolated or in combination with neoplasms. ${ }^{56,57}$ Some clinical and laboratory data provide evidence that suggests that ectopic endometrial lesions result in the dislocation of basal endometrial cells. ${ }^{58}$

Studies showed that endometriotic lesions express p63 differently; however, whether the lack of p63 expression in some lesions is related to the extent of the illness, to its clinical behavior, or to the exacerbation of the symptoms that accompany it is unclear. ${ }^{13}$

We have noted in our experimental model that the stain was more evident in ectopic endometria than in eutopic endometria $(p<0.0001)$, inferring a greater potential for differentiation in eutopic tissue, favoring the establishment of endometriosis, as it has already been suggested that p63positive cells in normal endometria represent cells with a stem cell phenotype that have the potential for multidirectional differentiation. ${ }^{12-16}$

Another relevant fact was the interference of the progression time of the lesion regarding the staining intensity, which could suggest that the longer the progression, the greater the ability of endometriotic foci in the ectopic tissue to differentiate.

\section{Conclusion}

Upon analyzing the different markers of cell proliferation and differentiation, as well as of tissue invasion in eutopic and ectopic endometria in the rabbits submitted to the induction of endometriotic lesions by the experimental model, 4 and 8 weeks after the endometrial implantation procedure, we conclude that the ectopic lesions seem to express a greater ability for cell proliferation and differentiation, as well as for tissue invasion when compared with eutopic endometria. This is evident in the greater intensity of the immunostaining for the proteins involved in the capacity to invade tissues (MMP-9 and TIMP-2) in ectopic endometria compared to the eutopic endometrium and in the higher number of cells of molecules involved in cell proliferation and differentiation (MT and p63) that were stained in ectopic endometria, which was most evident by the 63 stain in the endometrium after 8 weeks of progression. The ectopic endometrial lesions seem to express a greater ability for cell differentiation and tissue invasion than eutopic endometrial lesions, characterizing endometriosis as a potentially invasive, progressive, and heterogeneous disease in its presentation. However, more studies are necessary to better clarify the participation of these markers in the complex pathophysiological mechanism of endometriosis.

\section{Contributors}

All authors contributed to the conception and design, data collection or analysis and interpretation of data, as well as to the writing of the article or critical review of the intellectual content and to the final approval of the version to be published.

\section{Conflicts of Interest}

The authors have no conflicts of interest to declare.

\section{Acknowledgments}

The authors thank Rosangela Orlandin Lopes for the excellent technical assistance. This work was supported by the National Council for Scientific and Technological Development (CNPq, in the Portuguese acronym), Universal Project: Procedure 47210 /2009-1-Research Support.

\section{References}

1 Burney RO, Giudice LC. Pathogenesis and pathophysiology of endometriosis. Fertil Steril 2012;98(03):511-519 Doi: 10.1016/ j.fertnstert.2012.06.029

2 Augoulea A, Alexandrou A, Creatsa M, Vrachnis N, Lambrinoudaki I. Pathogenesis of endometriosis: the role of genetics, inflammation and oxidative stress. Arch Gynecol Obstet 2012;286(01): 99-103 Doi: 10.1007/s00404-012-2357-8

3 Chung HW, Wen Y, Chun SH, Nezhat C, Woo BH, Lake Polan M. Matrix metalloproteinase-9 and tissue inhibitor of metalloproteinase-3 mRNA expression in ectopic and eutopic endometrium in women with endometriosis: a rationale for endometriotic invasiveness. Fertil Steril 2001;75(01):152-159 Doi: 10.1016/ S0015-0282(00)01670-8

4 Chung HW, Lee JY, Moon HS, et al. Matrix metalloproteinase-2, membranous type 1 matrix metalloproteinase, and tissue inhibitor of metalloproteinase-2 expression in ectopic and eutopic endometrium. Fertil Steril 2002;78(04):787-795 Doi: 10.1016/ S0015-0282(02)03322-8

5 Uzan C, Cortez A, Dufournet C, Fauvet R, Siffroi JP, Daraï E. Eutopic endometrium and peritoneal, ovarian and bowel endometriotic tissues express a different profile of matrix metalloproteinases-2, -3 and -11 , and of tissue inhibitor metalloproteinases- 1 and -2 . Virchows Arch 2004;445(06):603-609 Doi: 10.1007/s00428-004$1117-\mathrm{y}$

6 Ria R, Loverro G, Vacca A, et al. Angiogenesis extent and expression of matrix metalloproteinase- 2 and -9 agree with progression of ovarian endometriomas. Eur J Clin Invest 2002;32(03):199-206 Doi: 10.1046/j.1365-2362.2002.00960.x

7 Sotnikova NY, Antsiferova YS, Posiseeva LV, Shishkov DN, Posiseev DV, Filippova ES. Mechanisms regulating invasiveness and growth of endometriosis lesions in rat experimental model and in humans. Fertil Steril 2010;93(08):2701-2705 Doi: 10.1016/j. fertnstert.2009.11.024

8 Wenzl RJ, Heinzl H. Localization of matrix metalloproteinase-2 in uterine endometrium and ectopic implants. Gynecol Obstet Invest 1998;45(04):253-257 Doi: 10.1159/000009978

9 Becker CM, Louis G, Exarhopoulos A, et al. Matrix metalloproteinases are elevated in the urine of patients with endometriosis. Fertil Steril 2010;94(06):2343-2346 Doi: 10.1016/j.fertnstert.2010.02.040

10 Liu XJ, He YL, Peng DX. Expression of metalloproteinase-9 in ectopic endometrium in women with endometriosis. J First Mil Med Univ 2002;22(05):467-469

11 Collette T, Bellehumeur C, Kats R, et al. Evidence for an increased release of proteolytic activity by the eutopic endometrial tissue in women with endometriosis and for involvement of matrix 
metalloproteinase-9. Hum Reprod 2004;19(06):1257-1264 Doi: 10.1093/humrep/deh290

12 O'Connell JT, Mutter GL, Cviko A, et al. Identification of a basal/ reserve cell immunophenotype in benign and neoplastic endometrium: a study with the p53 homologue p63. Gynecol Oncol 2001;80(01):30-36 Doi: 10.1006/gyno.2000.6026

13 Poli Neto OB, Ferreira HM, Ramalho LN, Rosa e Silva JC, Candido dos Reis FJ, Nogueira AA. Expression of p63 differs in peritoneal endometriosis, endometriomas, adenomyosis, rectovaginal septum endometriosis, and abdominal wall endometriosis. Arch Pathol Lab Med 2007;131(07):1099-1102 Doi: 10.1043/15432165(2007)131[1099:EOPDIP]2.0.CO;2

14 Gargett CE, Masuda H. Adult stem cells in the endometrium. Mol Hum Reprod 2010;16(11):818-834 Doi: 10.1093/molehr/gaq061

15 Maruyama T, Yoshimura Y. Stem cell theory for the pathogenesis of endometriosis. Front Biosci (Elite Ed) 2012;4:2754-2763

16 Oliveira FR, Dela Cruz C, Del Puerto HL, Vilamil QT, Reis FM, Camargos AF. Stem cells: are they the answer to the puzzling etiology of endometriosis? Histol Histopathol 2012;27(01):23-29 Doi: 10.14670/HH-27.23

17 Ioachim EE, Kitsiou E, Carassavoglou C, Stefanaki S, Agnantis NJ. Immunohistochemical localization of metallothionein in endometrial lesions. J Pathol 2000;191(03):269-273 Doi: 10.1002/ 1096-9896(2000)9999:9999<:AID-PATH616>3.0.CO;2-Q

18 Madej P, Madej JA, Kamiński K, et al. [Immunohistochemical localisation of metallothionein in ovarian endometriosis in women]. Ginekol Pol 2003;74(11):1456-1464

19 Wicherek L, Dutsch-Wicherek M, Galazka K, et al. Comparison of RCAS1 and metallothionein expression and the presence and activity of immune cells in human ovarian and abdominal wall endometriomas. Reprod Biol Endocrinol 2006;4:41

20 Salamonsen LA. Matrix metalloproteinases and their tissue inhibitors in endocrinology. Trends Endocrinol Metab 1996;7(01): 28-34 Doi: 10.1016/1043-2760(95)00189-1

21 Busiek DF, Baragi V, Nehring LC, Parks WC, Welgus HG. Matrilysin expression by human mononuclear phagocytes and its regulation by cytokines and hormones. J Immunol 1995;154(12):6484-6491

22 Jeziorska M, Nagase H, Salamonsen LA, Woolley DE. Immunolocalization of the matrix metalloproteinases gelatinase $B$ and stromelysin 1 in human endometrium throughout the menstrual cycle. J Reprod Fertil 1996;107(01):43-51

23 Shi W, Mognetti B, Campana A, Bischof P. Metalloproteinase secretion by endometrial leukocyte subsets. Am J Reprod Immunol 1995; 34(05):299-310 Doi: 10.1111/j.1600-0897.1995.tb00956.x

24 Yang A, Kaghad M, Wang Y, et al. p63, a p53 homolog at 3q27-29, encodes multiple products with transactivating, death-inducing, and dominant-negative activities. Mol Cell 1998;2(03):305-316 Doi: 10.1016/S1097-2765(00)80275-0

25 Yang A, Schweitzer R, Sun D, et al. p63 is essential for regenerative proliferation in limb, craniofacial and epithelial development. Nature 1999;398(6729):714-718 Doi: 10.1038/19539

26 Theocharis SE, Margeli AP, Klijanienko JT, Kouraklis GP. Metallothionein expression in human neoplasia. Histopathology 2004; 45(02):103-118 Doi: 10.1111/j.1365-2559.2004.01922.x

27 Levadoux-Martin M, Hesketh JE, Beattie JH, Wallace HM. Influence of metallothionein-1 localization on its function. Biochem J 2001;355(Pt 2):473-479 Doi: 10.1042/bj3550473

28 Chiaverini N, De Ley M. Protective effect of metallothionein on oxidative stress-induced DNA damage. Free Radic Res 2010;44 (06):605-613 Doi: 10.3109/10715761003692511

29 Manyak MJ, Nelson LM, Solomon D, DeGraff W, Stillman RJ, Russo A. Fluorescent detection of rabbit endometrial implants resulting from monodispersed viable cell suspensions. Fertil Steril 1990;54 (02):356-359 Doi: 10.1016/S0015-0282(16)53720-0

30 Hahn DW, Carraher RP, Foldesy RG, McGuire JL. Development of an animal model for quantitatively evaluating effects of drugs on endometriosis. Fertil Steril 1985;44(03):410-415 Doi: 10.1016/ S0015-0282(16)48869-2
31 Schor E, Baracat EC, Simões MJ, de Freitas V, Giannotti Filho O, de Lima GR. Effects of conjugated estrogens and progestogen in surgically induced endometriosis in oophorectomized rats. Clin Exp Obstet Gynecol 1999;26(3-4):158-161

32 Rosa e Silva JC, Rosa e Silva ACJS, Coltro PS, Garcia SB, Cândido dos Reis FJ, Nogueira AA. [Experimental endometriosis model in rabbits with follow-up of the lesions. Rev Bras Ginecol Obstet 2004;26:715-719 Doi: 10.1590/S0100-72032004000900007

33 Schenken RS, Asch RH. Surgical induction of endometriosis in the rabbit: effects on fertility and concentrations of peritoneal fluid prostaglandins. Fertil Steril 1980;34(06):581-587 Doi: 10.1016/ S0015-0282(16)45199-X

34 Schor E, Freitas V, Soares JJ, Simões M, Baracat E. [Endometriosis: experimental model in rats]. Rev Bras Ginecol Obstet 1999; 21:281-284 Doi: 10.1590/S0100-72031999000500006

35 Zhou HE, Nothnick WB. The relevancy of the matrix metalloproteinase system to the pathophysiology of endometriosis. Front Biosci 2005;10:569-575

36 Osteen KG, Bruner KL, Sharpe-Timms KL. Steroid and growth factor regulation of matrix metalloproteinase expression and endometriosis. Semin Reprod Endocrinol 1996;14(03):247-255 Doi: $10.1055 / \mathrm{s}-2007-1016334$

37 Bruner-Tran KL, Eisenberg E, Yeaman GR, Anderson TA, McBean J, Osteen KG. Steroid and cytokine regulation of matrix metalloproteinase expression in endometriosis and the establishment of experimental endometriosis in nude mice. J Clin Endocrinol Metab 2002;87(10):4782-4791 Doi: 10.1210/jc.2002-020418

38 Chen JL, Lin QH, Fang XL, Tao GS, Huang FY. [Effect of progesterone on the secretion of matrix metalloproteinase- 2 and matrix metalloproteinase-9 in human ectopic endometrial stromal cells]. Zhong Nan Da Xue Xue Bao Yi Xue Ban 2005;30(03): 307-311

39 Bruner KL, Matrisian LM, Rodgers WH, Gorstein F, Osteen KG. Suppression of matrix metalloproteinases inhibits establishment of ectopic lesions by human endometrium in nude mice. J Clin Invest 1997;99(12):2851-2857 Doi: 10.1172/JCI119478

40 Gilabert-Estellés J, Ramón LA, España F, et al. Expression of angiogenic factors in endometriosis: relationship to fibrinolytic and metalloproteinase systems. Hum Reprod 2007;22(08): 2120-2127 Doi: 10.1093/humrep/dem149

41 Sillem M, Prifti S, Koch A, Neher M, Jauckus J, Runnebaum B. Regulation of matrix metalloproteinases and their inhibitors in uterine endometrial cells of patients with and without endometriosis. Eur J Obstet Gynecol Reprod Biol 2001;95(02):167-174 Doi: 10.1016/S0301-2115(00)00415-2

42 Szamatowicz J, Laudański P, Tomaszewska I. Matrix metalloproteinase- 9 and tissue inhibitor of matrix metalloproteinase-1: a possible role in the pathogenesis of endometriosis. Hum Reprod 2002;17(02):284-288 Doi: 10.1093/humrep/17.2.284

43 Gilabert-Estellés J, Estellés A, Gilabert J, et al. Expression of several components of the plasminogen activator and matrix metalloproteinase systems in endometriosis. Hum Reprod 2003;18(07): 1516-1522 Doi: 10.1093/humrep/deg300

$44 \mathrm{Li} \mathrm{Y,} \mathrm{Lang} \mathrm{JH.} \mathrm{[Expressions} \mathrm{of} \mathrm{matrix} \mathrm{metalloproteinase-9} \mathrm{and}$ tissue inhibitor of metalloproteinase-1 mRNA in endometriosis]. Zhonghua Fu Chan Ke Za Zhi 2006;41(01):30-33

45 Collette T, Maheux R, Mailloux J, Akoum A. Increased expression of matrix metalloproteinase- 9 in the eutopic endometrial tissue of women with endometriosis. Hum Reprod 2006;21(12):3059-3067 Doi: 10.1093/humrep/del297

46 Pitsos M, Kanakas N. The role of matrix metalloproteinases in the pathogenesis of endometriosis. Reprod Sci 2009;16(08):717-726 Doi: $10.1177 / 1933719109333661$

47 Amălinei C, Căruntu ID, Giuşcă SE, Bălan RA. Matrix metalloproteinases involvement in pathologic conditions. Rom J Morphol Embryol 2010;51(02):215-228

48 Malik S, Day K, Perrault I, Charnock-Jones DS, Smith SK. Menstrual effluent in endometriosis shows no difference in volume, VEGF-A, 
MMP2 and MMP9 or sFLT. Reprod Biomed Online 2006;12(02): 174-181

49 Vinatier D, Cosson M, Dufour P. Is endometriosis an endometrial disease? Eur J Obstet Gynecol Reprod Biol 2000;91(02):113-125 Doi: 10.1016/S0301-2115(99)00263-8

50 Nisolle M, Donnez J. Peritoneal endometriosis, ovarian endometriosis, and adenomyotic nodules of the rectovaginal septum are three different entities. Fertil Steril 1997;68(04):585-596 Doi: 10.1016/S0015-0282(97)00191-X

51 Klimek M, Wicherek L, Galazka K, et al. Cycle dependent expression of endometrial metallothionein. Neuroendocrinol Lett 2005; 26(06):663-666

52 Wicherek L, Popiela TJ, Galazka K, et al. Metallothionein and RCAS1 expression in comparison to immunological cells activity in endometriosis, endometrial adenocarcinoma and endometrium according to menstrual cycle changes. Gynecol Oncol 2005;99(03):622-630 Doi: 10.1016/j.ygyno.2005. 07.003
53 Quade BJ, Yang A, Wang Y, et al. Expression of the p53 homologue p63 in early cervical neoplasia. Gynecol Oncol 2001;80(01):24-29 Doi: 10.1006/gyno.2000.5953

54 Martens JE, Arends J, Van der Linden PJ, De Boer BA, Helmerhorst TJ. Cytokeratin 17 and p63 are markers of the HPV target cell, the cervical stem cell. Anticancer Res 2004;24(2B):771-775

55 Houghton O, McCluggage WG. The expression and diagnostic utility of p63 in the female genital tract. Adv Anat Pathol 2009; 16(05):316-321 Doi: 10.1097/PAP.0b013e3181b507c6

56 Di Como CJ, Urist MJ, Babayan I, et al. p63 expression profiles in human normal and tumor tissues. Clin Cancer Res 2002;8(02):494-501

57 Poli Neto OB, Candido Dos Reis FJ, Zambelli Ramalho LN, Nogueira AA, de Andrade JM. p63 expression in epithelial ovarian tumors. Int J Gynecol Cancer 2006;16(01):152-155 Doi: 10.1111/j.15251438.2006.00290.x

58 Leyendecker G, Herbertz M, Kunz G, Mall G. Endometriosis results from the dislocation of basal endometrium. Hum Reprod 2002;17 (10):2725-2736 Doi: 10.1093/humrep/17.10.2725 